\title{
Last Glacial Maximum equilibrium-line altitudes and paleoclimate, northern Uinta Mountains, Utah, U.S.A.
}

\author{
Jeffrey S. MUNROE, ${ }^{*}$ DAvid M. MICKELSON \\ Department of Geology and Geophysics, University of Wisconsin-Madison, 1215 West Dayton Steet, Madison, Wisconsin 53706-1490, U.S.A. \\ E-mail:jmunroe@middlebury.edu
}

\begin{abstract}
Nineteen former valley glaciers were reconstructed for their Last Glacial Maximum (LGM) extents in the northern Uinta Mountains, Utah, U.S.A. Mean equilibrium-line altitudes (ELAs) calculated by four methods (accumulation-area ratio, toeheadwall altitude ratio, lateral moraines and cirque floors) range from 3050 to $3300 \mathrm{~m}$ a.s.l. Modern mean summer temperatures $\left(T_{\mathrm{S}}\right)$ at the ELAs range from $8.7^{\circ}$ to $11.2^{\circ} \mathrm{C}$, while modern winter precipitation $(P)$ ranges from 354 to $590 \mathrm{~mm}$ snow water equivalent (SWE). Based on the difference in elevation of mean ELAs across the range, LGM $P$ values must have ranged from 940 to $3040 \mathrm{~mm}$ SWE, assuming the modern summer lapse rate was the same during the LGM. A $T_{\mathrm{s}}$ depression of $5.5^{\circ} \mathrm{C}$ is required for these precipitation values to plot in the range of modern ELA values. The reconstructed increase in $P$ at the western end of the range is 10 times the modern increase, reflecting the influence of pluvial Lake Bonneville. Assuming ELA depression ( $\triangle \mathrm{ELA})$ resulted from this $P$ increase and a uniform $5.5^{\circ} \mathrm{C} T_{\mathrm{s}}$ decrease, the regional LGM $\Delta$ ELA was approximately $900 \mathrm{~m}$.
\end{abstract}

\section{INTRODUCTION}

Reconstruction of the equilibrium-line altitudes (ELAs) of past glaciers can provide information about the climatic conditions responsible for sustaining these glaciers at their maximum positions. The equilibrium line is a hypothetical line across a glacier surface that divides the glacier into an upper accumulation zone where mass is gained, and a lower ablation zone where mass is lost during the course of a balance year (Paterson, 1994). Numerous previous studies have presented techniques for ELA calculation (Pierce, 1979; Meierding, 1982; Porter and others, 1983; Leonard, 1984; Brugger, 1996). All of these methods rely on field data, including terminal moraine elevations, the maximum altitude attained by continuous lateral moraines, and the glacier area-altitude distribution determined through reconstruction of the glacier dimensions from the geomorphic record. Investigations on modern glaciers have constrained the range of mean summer temperature and mean winter (or annual) precipitation common to equilibrium lines (Loewe, 1971; Leonard, 1989; Ohmura and others, 1992). Therefore, calculation of late-Pleistocene ELAs and determination of the modern conditions at these elevations allows estimation of Last Glacial Maximum (LGM) temperature and precipitation values relative to modern conditions.

Improved understanding of the distribution of glaciers in the Uinta Mountains, Utah, U.S.A., during the LGM serves to link the relatively well-studied ranges of the middle

\footnotetext{
* Present address: Geology Department, Middlebury College, Middlebury, Vermont 05753, U.S.A.
}

Rockies with the Sierra Nevada and other ranges of the Great Basin (e.g. Fullerton, 1986; Zielinski and McCoy, 1987; Leonard, 1989; Osborn, 1989; Gillespie, 1991; Bursik and Gillespie, 1993). This is the first study to reconstruct the glaciers of the northern Uintas from modern field mapping and to interpret the gradient of former ELAs. The unique east-west orientation of the Uintas and their location along a major air-mass boundary makes them ideal for study of the late glacial climate in the Rocky Mountains. Furthermore, glaciers in the Uintas at the LGM were discrete, with little or no confluence between adjacent valleys, allowing former accumulation areas to be delineated with high fidelity. Finally, a dense network of weather stations provides data on modern climatic conditions in the range including air temperature, mean annual precipitation and winter snowfall.

\section{SETTING}

The Uinta Mountains are a Laramide-age uplift of Precambrian metasedimentary rocks that extends over $150 \mathrm{~km}$ across northeastern Utah from the Wasatch Mountains into northwestern Colorado (Bryant, 1992) (Fig. 1). They are the longest east-west-trending mountain range in the continental United States and contain the highest mountains in Utah, with summit elevations $>4000 \mathrm{~m}$ a.s.l. No glaciers are present in the Uintas today, but terminal moraine complexes, continuous lateral moraines and extensive outwash valley trains formed during the LGM. The LGM is locally known as the "Smiths Fork Glaciation" and is considered to be equivalent to the "Pinedale Glaciation" of the Wind River Mountains (Richmond, 1965; Bryant, 1992).

Based on records from snowpack telemetry (SNOTEL) sites, mean annual precipitation varies from 550 to $925 \mathrm{~mm} \mathrm{a}^{-1}$ 

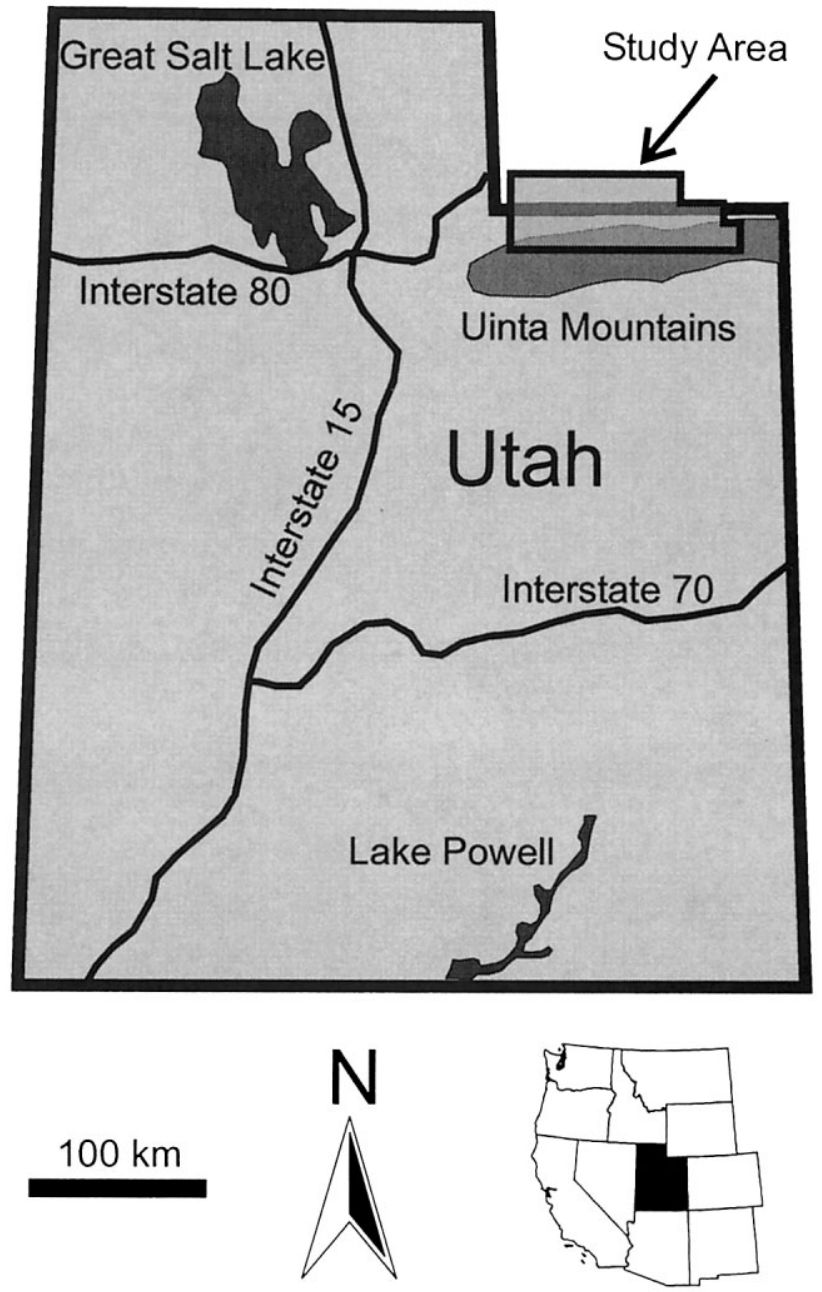

Fig 1. Location of the Uinta Mountains and the study area in northeastern Utah.

at elevations of 2650-3300 ma.s.l. The percentage of mean annual precipitation falling as snow increases linearly with elevation, and exceeds $60 \%$ above $3300 \mathrm{~m}$ a.s.l. The mean annual air temperature at elevations over $\sim 3100 \mathrm{~m}$ is $<0^{\circ} \mathrm{C}$.

\section{PREVIOUS STUDIES}

Atwood (1909) first studied the glacial geology of the Uintas, concluding that the lower limit of glaciation rose eastward, presumably due to less snowfall near the eastern end of the range. A recent attempt to reconstruct ELAs in the Uintas was made by Schlenker (1995). Using the mapping of Atwood (1909), and 1972-90 snow accumulation data, Schlenker determined the elevation of the modern ELA and the magnitude of LGM ELA depression. However, his analysis is limited by reliance on Atwood's mapping and by errors associated with averaging SNOTEL records of varying lengths. Greatly improved topographic map bases, the availability of aerial photography, and application of a geographic information system (GIS) in this study allow for more detailed and accurate geomorphic mapping, which forms the basis for the ELA calculations.

\section{METHODS}

\section{Mapping}

Glacial features in 19 drainages of the northern Uintas were mapped during the summers of 1998-2000 (Fig. 2). Lateral moraines, end moraines and heads of outwash were identified through map and air-photo interpretation and checked in the field. Glacial limits were correlated between adjacent valleys based on position, elevation, cross-cutting relationships of outwash valley trains and the extent of weathering. Direct absolute ages are not available for these deposits. Mapping was compiled in a GIS, and the dimensions of the glaciers during the Smiths Fork Glaciation were reconstructed from the distribution of ice-marginal features, including terminal and lateral moraines. All glacier reconstructions were fieldchecked to assess their validity.

\section{Calculation of ELAs}

Four separate methods were used to calculate the elevations of equilibrium lines for each of the reconstructed glaciers:

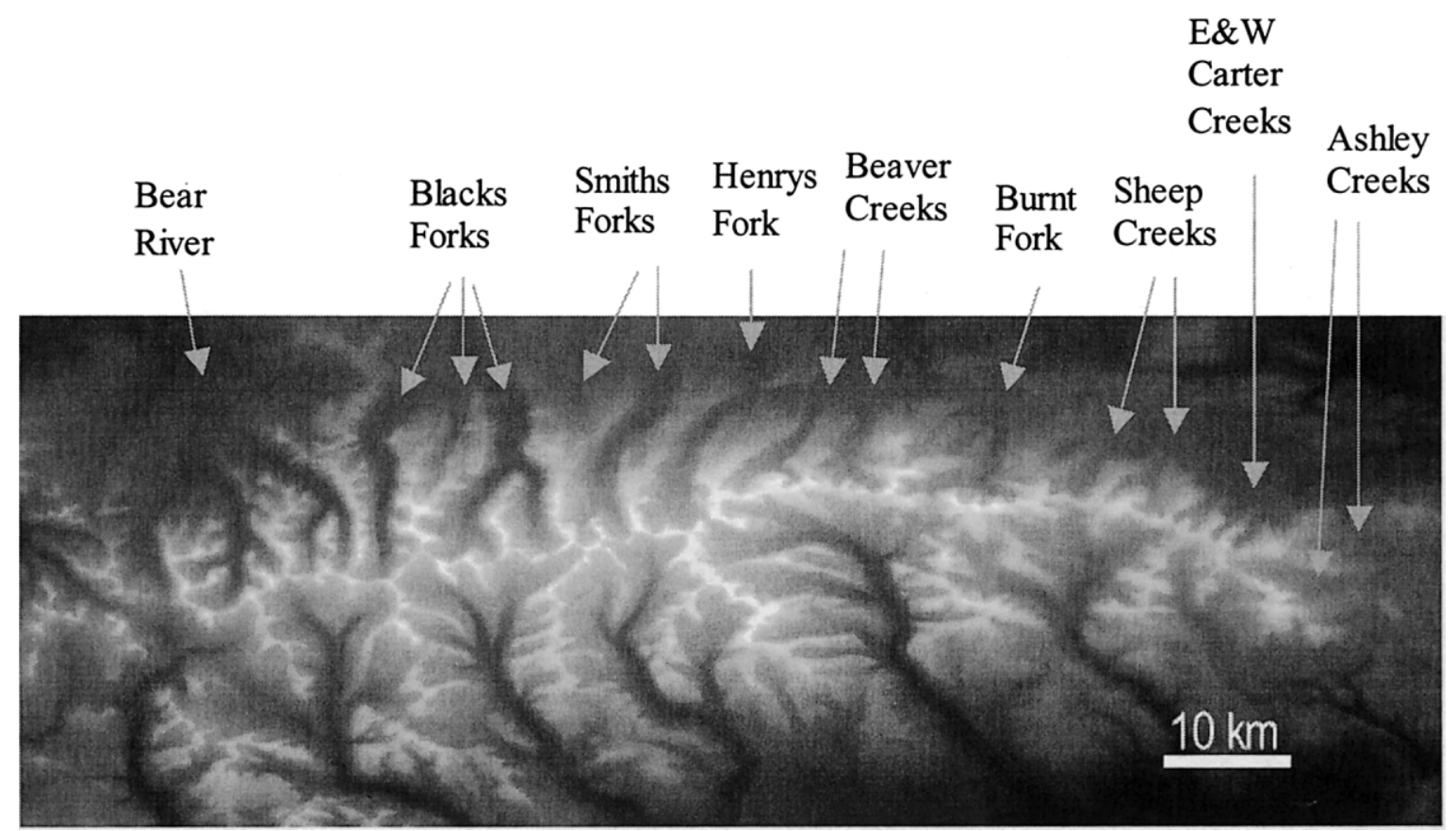

Fig. 2. Three-arcsecond digital elevation model of the Uinta Mountains showing drainages of the northern Uintas. Lower elevations are represented by darker shades. The highest elevations in the center of the range are $>4000$ m a.s.l. 
accumulation-area ratio $(\mathrm{AAR})$, toe-headwall altitude ratio, highest elevation of continuous lateral moraines, and cirque-floor elevations.

The AAR method is based on the observation that the majority of modern glaciers have an "accumulation-area" to "total-area" ratio of 0.50-0.65 when they are in equilibrium (Meier and Post, 1962). Geomorphic features delineating the former ice margin are used to determine the area covered by the glacier, and the ELA is then located at the elevation of a line dividing the reconstructed area in the proportions seen on modern glaciers. The AAR technique has been applied to glacier systems all over the world, including New Zealand (Porter, 1975), Hawaii (Porter, 1979), the Cascades of Oregon (Scott, 1977) and Baffin Island (Hawkins, 1985). Meierding (1982) determined that a ratio of 0.65 provided the lowest rms error in his analysis of glaciers in the Colorado Front Range. Torsnes and others (1993) supported this conclusion with their study of modern glaciers in western Norway. For this study, glacier outlines determined from field mapping were digitized into a GIS from which the area of the glacier was calculated. The elevation of a line that assigned $65 \%$ of this glacier area to the accumulation area was determined iteratively.

The AAR method is best applied to glaciers with relatively simple area-altitude distributions. Application of the AAR technique to glaciers with skewed hypsometry, such as ice fields or piedmont glaciers, can yield erroneous results. Previous researchers have attempted to correct for this by using a lower AAR ( 0.50$)$ for glaciers known from reconstructions to have had piedmont glacier morphology (e.g. Brugger and Goldstein, 1999). Accordingly, an AAR of 0.50 was used in the calculation of the final weighted ELAs for the five piedmont glaciers in the northern Uintas. As an additional check on the uniformity of glacier hypsometry, the glacier area above a given elevation was determined at $100 \mathrm{~m}$ intervals from the terminus to the headwall. The coefficients of determination $\left(r^{2}\right)$ for linear regressions fit to these data were used to evaluate the uniformity of the overall area-altitude distribution of the reconstructed glaciers and their suitability for the AAR method.

The toe-headwall altitude ratio (THAR) method has also been used to determine ELAs. The equilibrium lines on modern glaciers are usually located at an elevation above the terminus that is equivalent to $35-40 \%$ of the total elevation difference between the terminus and top of the glacier. The lowest elevation of ice is readily calculated from the elevation of the glacier terminal moraine. The highest elevation that a glacier reached on a cirque headwall is harder to determine, especially in areas of intense postglacial mass wasting. Meierding (1982) estimated the upper elevation of glacial ice as the highest point on the cirque headwall with a slope of $<60^{\circ}$. He found a THAR of $0.35-0.40$ yielded the lowest error and was comparable to the AAR method in its accuracy. In this study the glacier-toe elevation was taken as the lowest elevation along the top of the terminal moraine. The highest extent was taken as the highest contour below the near-vertical part of the upper headwall, and a THAR of 0.40 was applied to locate the ELA.

A third method for estimating ELAs, the lateral moraine (LM) method, involves the identification of lateral moraines in glaciated valleys. For a glacier in equilibrium, ice flows away from the margins in the accumulation area and toward the margins in the ablation area. Sediment is brought to the margins to form moraines, therefore, only in the ablation area. Thus, the elevation of lateral moraines farthest upglacier should coincide with the ELA. This method may underestimate the ELA where lateral moraines have been affected by postglacial erosion. To reduce errors associated with postglacial erosion of moraines, the ELA was estimated by tracing continuous lateral moraine crests upslope from the terminal moraine on both sides of the valley. This approach allowed projection of lateral moraines across gaps where moraine segments had been removed by mass wasting.

A final method for estimating former ELAs, the cirquefloor (CIR) method, involves measurement of cirque-floor elevations in glaciated drainages. Determining the elevation of cirque floors with a similar aspect yields an estimate of the ELA (Flint, 1971). Such estimates often have large errors because cirque floors reflect the erosive effects of multiple glaciations, all of which may have had different ELAs. Weakly developed lower-elevation cirques are also difficult to identify (Meierding, 1982). Well-developed cirques are abundant in the northern Uintas, though, facilitating application of this method and increasing its utility. Therefore, the elevation of the slope break between the headwall and cirque floor in the lowest north-to-east-facing cirque was recorded for each glaciated valley.

\section{Galculation of the weighted ELA}

The values derived through each of these four methods were combined to produce a weighted average ELA for each of the Smiths Fork-age glaciers, similar to the method of Locke (1990). Estimates obtained through the AAR method were given a weight of 4 , the THAR method 3 , the LM method 2 and the CIR method 1. The weights assigned in this study are qualitative, reflecting the estimated accuracy and precision of the methods and the success other researchers have had in their application (e.g. Meierding, 1982; Locke, 1990).

AAR values of 0.65 were used in the weighted average for all glaciers except for the South Fork Ashley Creek (No. 1), the East and West Forks Carter Creek (Nos. 3 and 4) and the South and Middle Forks Sheep Creek (Nos. 5 and 6) (see Fig. 1). Reconstructions based on field mapping showed that these five glaciers had a piedmont morphology at their maximum position that skewed their area-altitude distribution. Accordingly, an AAR value of 0.50 was used in the weighted average for these valleys.

\section{Determination of modern temperatures at the ELAs}

Mean annual $\left(T_{\mathrm{a}}\right)$ and mean summer $\left(T_{\mathrm{s}}\right.$; June-August) air temperatures were determined for four SNOTEL sites in the northern Uintas and one remote automated weather station (RAWS) on the Uinta ridge crest. These were combined with average temperatures for Manilla, Utah and Evanston, Wyoming, to produce an elevational transect ranging from 1936 to $3697 \mathrm{~m}$ a.s.l. A linear regression for these data was then used to determine the modern $T_{\mathrm{a}}$ and $T_{\mathrm{s}}$ at each of the reconstructed ELAs.

\section{Determination of modern winter accumulation at the ELAs}

The water contained within the snowpack at the locations of the ELAs in the northern Uintas was determined based on the methods of Pierce (1982) and Leonard (1984). Snow-accumulation records (Table 1) from 16 SNOTEL sites in the glaciated section of the Uinta Mountains for the years 1986- 
Table 1. Summary data and locations for 16 SNOTEL sites in the Uinta Mountains, 1989-99

\begin{tabular}{|c|c|c|c|c|c|}
\hline SNOTEL station & $\begin{array}{c}\text { Eleva- } \\
\text { tion } \\
\text { m }\end{array}$ & Location & $\begin{array}{l}\text { 1 April } \\
\text { SWE } \\
\mathrm{mm}\end{array}$ & $\begin{array}{l}\text { Max. } \\
\text { SWE } \\
\text { mm }\end{array}$ & $\begin{array}{c}\text { Date of } \\
\max .\end{array}$ \\
\hline Brown Duck Ridge & 3212 & $40^{\circ} 35^{\prime} \mathrm{N}, 110^{\circ} 35^{\prime} \mathrm{W}$ & 445 & 547 & 4 May \\
\hline Chepeta & 3121 & $40^{\circ} 46^{\prime} \mathrm{N}, 110^{\circ} 00^{\prime} \mathrm{W}$ & 371 & 422 & 18 Apr. \\
\hline Five Points Lake & 3309 & $40^{\circ} 43^{\prime} \mathrm{N}, 110^{\circ} 28^{\prime} \mathrm{W}$ & 436 & 511 & 29 Apr. \\
\hline Hayden Fork & 2758 & $40^{\circ} 48^{\prime} \mathrm{N}, 110^{\circ} 53^{\prime} \mathrm{W}$ & 379 & 411 & 9 Apr. \\
\hline Hewinta GS & 2879 & $40^{\circ} 57^{\prime} \mathrm{N}, 110^{\circ} 29^{\prime} \mathrm{W}$ & 283 & 323 & 15 Apr. \\
\hline Hickerson Park & 2758 & $40^{\circ} 54^{\prime} \mathrm{N}, 110^{\circ} 58^{\prime} \mathrm{W}$ & 203 & 238 & 9 Apr. \\
\hline Hole in the Rock & 2773 & $40^{\circ} 55^{\prime} \mathrm{N}, 110^{\circ} 12^{\prime} \mathrm{W}$ & 184 & 234 & 12 Apr. \\
\hline Kings Cabin - Upper & 2645 & $40^{\circ} 43^{\prime} \mathrm{N}, 110^{\circ} 33^{\prime} \mathrm{W}$ & 244 & 287 & 6 Apr. \\
\hline Lake Fork No. 1 & 3061 & $40^{\circ} 36^{\prime} \mathrm{N}, 110^{\circ} 26^{\prime} \mathrm{W}$ & 346 & 396 & 16 Apr. \\
\hline Lake Fork Basin & 3303 & $40^{\circ} 45^{\prime} \mathrm{N}, 110^{\circ} 37^{\prime} \mathrm{W}$ & 514 & 633 & 2 May \\
\hline Lily Lake & 2742 & $40^{\circ} 52^{\prime} \mathrm{N}, 110^{\circ} 48^{\prime} \mathrm{W}$ & 327 & 365 & 17 Apr. \\
\hline Mosby Mountain & 2879 & $40^{\circ} 37^{\prime} \mathrm{N}, 109^{\circ} 53^{\prime} \mathrm{W}$ & 306 & 380 & 18 Apr. \\
\hline Rock Creek & 2394 & $40^{\circ} 33^{\prime} \mathrm{N}, 110^{\circ} 41^{\prime} \mathrm{W}$ & 204 & 235 & 26 May \\
\hline Steel Creek Park & 3061 & $40^{\circ} 55^{\prime} \mathrm{N}, 110^{\circ} 30^{\prime} \mathrm{W}$ & 383 & 507 & 7 May \\
\hline Trial Lake & 3018 & $40^{\circ} 41^{\prime} \mathrm{N}, 110^{\circ} 57^{\prime} \mathrm{W}$ & 593 & 691 & 26 Apr. \\
\hline Trout Creek & 2848 & $40^{\circ} 44^{\prime} \mathrm{N}, 109^{\circ} 40^{\prime} \mathrm{W}$ & 261 & 305 & 11 Apr. \\
\hline Mean & 2923 & - & 342 & 405 & 18 Apr. \\
\hline
\end{tabular}

1999 were utilized (United States National Resource and Conservation Service, http://www.wcc.nrcs.usda.gov/water/ wdata.html). The locations of these stations, their mean 1 April water equivalent and their mean annual maximum water equivalent were digitized into the GIS, allowing interpolation of a trend surface representing modern snow accumulation in the Uintas. Linear regressions between SNOTEL elevation and both 1 April and maximum water equivalent were determined, allowing prediction of 1 April and maximum water equivalent at any elevation.

Residuals were then calculated for each SNOTEL site between the measured and predicted values. A second surface was interpolated for these residuals in the GIS, yielding a representation of the deviation from altitude-predicted snowfall. Major departures identify areas in the modern Uintas that are relatively snow-starved, as well as those that receive more snow than would be expected given their elevation.

Precipitation at each of the 19 ELAs was calculated through two steps. First, the linear regression for SNOTEL elevation and mean annual maximum water equivalent was used to estimate the water content of the snowpack based solely on elevation. Then these values were adjusted by querying the surface interpolated from the residuals in the GIS to yield a local correction factor that was applied to the altitude-predicted value. This final estimate represents the modern winter water accumulation $(P)$ at each of the ELAs, taking into account both the elevation and location of the ELA within the modern snowfall distribution.

\section{Calculation of the differences between modern and LGM paleoclimate}

The values for modern $T_{\mathrm{s}}$ and $P$ for the locations of each of the ELAs were compared with the range of $T_{\mathrm{s}}$ and $P$ found at modern glacier equilibrium lines (Leonard, 1984; Brugger and Goldstein, 1999). Because two variables are involved, this analysis cannot yield a unique solution. However, the range of changes in $T_{\mathrm{s}}$ and $P$ required to shift these parameters from their modern values to those known to exist at modern glacier ELAs can be determined.
Table 2. Estimated ELAs ( $m$ ) for Smiths Fork-age glaciers

\begin{tabular}{|c|c|c|c|c|c|}
\hline Glacier & $A A R 0.65$ & $\begin{array}{c}\text { THAR } \\
0.4\end{array}$ & $\begin{array}{l}\text { Lateral } \\
\text { moraine }\end{array}$ & $\begin{array}{l}\text { Cirque } \\
\text { floor }\end{array}$ & $\begin{array}{c}\text { Weighted } \\
\text { ELA }\end{array}$ \\
\hline South Fork Ashley* & 3100 & 3040 & 3150 & 3333 & 3115 \\
\hline North Fork Ashley & 3160 & 3136 & 3078 & 3220 & 3142 \\
\hline East Fork Carter Creek ${ }^{*}$ & 3060 & 3048 & 3121 & 3212 & 3084 \\
\hline West Fork Carter Creek ${ }^{*}$ & 3140 & 3068 & 3130 & 3273 & 3130 \\
\hline South Fork Sheep Creek ${ }^{*}$ & 3170 & 3068 & 3080 & 3303 & 3135 \\
\hline Middle Fork Sheep Creek ${ }^{*}$ & 3130 & 3128 & 3055 & 3273 & 3129 \\
\hline Burnt Fork & 3210 & 3048 & 3160 & 3455 & 3176 \\
\hline Thompson Creek & 3125 & 3084 & 3139 & 3333 & 3136 \\
\hline Middle Fork Beaver Creek & 3210 & 3168 & 3225 & 3515 & 3231 \\
\hline West Fork Beaver Creek & 3230 & 3156 & 3212 & 3455 & 3227 \\
\hline Henrys Fork & 3130 & 3112 & 3280 & 3455 & 3187 \\
\hline Smiths Fork & 3045 & 3080 & 3103 & 3515 & 3114 \\
\hline West Fork Smiths & 3110 & 3136 & 3120 & 3333 & 3142 \\
\hline Blacks Fork & 3020 & 3036 & 3212 & 3273 & 3089 \\
\hline Little West Fork Blacks & 2990 & 2952 & 2970 & 3000 & 2976 \\
\hline East Fork Bear & 3035 & 2988 & 3188 & 3273 & 3075 \\
\hline Hayden Fork Bear River & 3025 & 2948 & 3188 & 3273 & 3059 \\
\hline Gold Hill & 2840 & 2888 & 2939 & 3152 & 2905 \\
\hline West Fork Bear & 2880 & 2788 & 2849 & 3030 & 2861 \\
\hline Mean & 3085 & 3046 & 3116 & 3299 & 3101 \\
\hline Std dev. & 105 & 98 & 106 & 143 & 97 \\
\hline$n$ & 19 & 19 & 19 & 19 & - \\
\hline
\end{tabular}

* $0.50 \mathrm{AAR}$

\section{RESULTS}

\section{ELA estimates}

Estimates of Smiths Fork-age ELAs obtained by the four methods described above are shown in Table 2. Given contour intervals of $20 \mathrm{ft}(6 \mathrm{~m})$ on the lower-elevation quadrangles, $40 \mathrm{ft}(12 \mathrm{~m})$ on the higher-elevation maps, and $50 \mathrm{ft}(15 \mathrm{~m})$ on the tightest network interpolated in the GIS, these estimates are considered accurate to within $\pm 7 \mathrm{~m}$. The CIR method yields the highest mean ELA (3300 $\mathrm{m}$ a.s.l.), while the THAR method yields the lowest mean estimate (3050 m a.s.l.). Values for the AAR and LM methods are intermediate (3090 and $3120 \mathrm{~m}$ a.s.l., respectively). This result is different than that obtained by Locke (1990) who reported that the LM method underestimated the others by about $230 \mathrm{~m}$, suggesting that LGM lateral moraines in the northern Uintas may be better preserved than those in western Montana. Standard deviations are similar for the AAR, THAR and LM methods, suggesting that these techniques were more successful in estimating the former ELA trend surface.

Statistics allowing comparison of the results obtained by the four methods for the Smiths Fork Glaciation are given in Table 3 (after Locke, 1990). The means are statistically indistinguishable (at $\alpha=0.001$ ) between the AAR and THAR methods ( $t$-statistic 24, $P=0.005), \mathrm{AAR}$ and LM methods $(t$-statistic $-1.56, P=0.137)$ and THAR and LM methods ( $t$-statistic $-67, P=0.002)$. In contrast, because the GIR method yielded higher estimates of ELAs, differences between the means derived from this method and the other three are highly significant $(P<0.001)$.

\section{Weighted ELAs}

Figure 3 illustrates the elevation of the weighted ELAs along the north slope of the range. The mean weighted ELA is $3100 \mathrm{~m}$ a.s.l. with a range of $2860-3230 \mathrm{~m}$ a.s.l. and 
Table 3. Summary statistics for Smiths Fork-age paleo-ELA estimates

\begin{tabular}{lcccc}
\hline & Moraines & Cirques & THAR 0.40 & AAR 0.65 \\
& & & & \\
\hline Moraines & $3116 \pm 106$ & 0.77 & 0.67 & 0.66 \\
Cirques & 19 & 1.9 & 1.9 & 1.9 \\
& $-8.62(0.0000)$ & $3299 \pm 143$ & 0.72 & 0.7 \\
THAR 0.40 & $-3.67(0.0017)^{*}$ & $-11.01(0.0000)$ & $3046 \pm 98$ & 0.87 \\
AAR 0.65 & 19 & 1.9 & 1.9 & 1.9 \\
& $-1.56(0.1371)^{*}$ & $-9.03(0.0000)$ & $3.24(0.0046)$ & $3085 \pm 107$ \\
& 19 & 1.9 & 19 & 1.9 \\
\hline
\end{tabular}

Notes: After Locke (1990, table 1). Diagonal is mean \pm 1 standard deviation, and number of measurements. Upper right is correlation coefficient $r$ and number of pairs. Lower left is $t$-statistic, $P$ value for paired two-sample test for means, and number of pairs. ${ }^{*}$ indicates pairs not significant at $\alpha<0.001$.

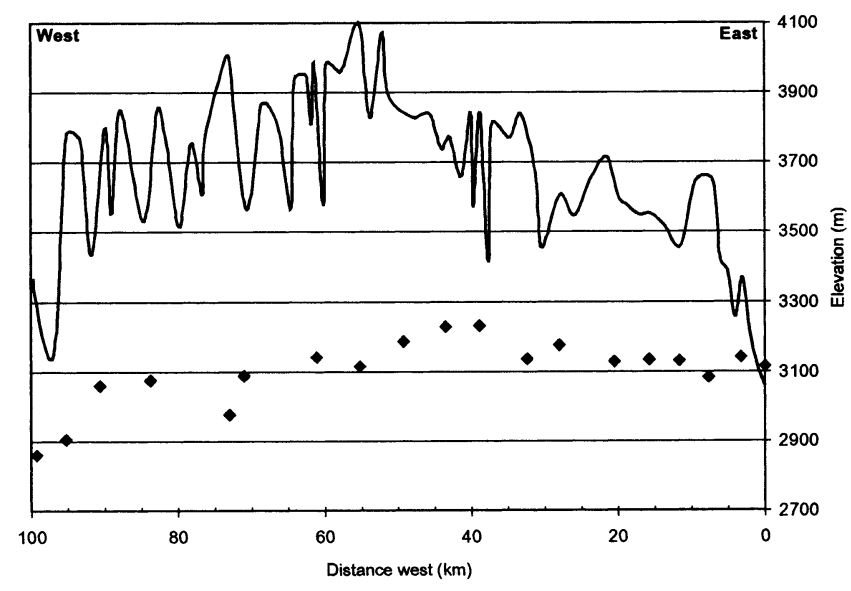

Fig. 3. Smiths Fork-age weighted ELAs across the north slope.

The Uinta ridge crest is shown for reference.

a standard deviation of $97 \mathrm{~m}$. ELAs are lowest at the western end of the north slope ( $\sim 2900$ m a.s.l.). In contrast, ELAs for the three glaciers in the center of the north slope are 80$130 \mathrm{~m}$ above the mean value. The ELA gradient over the western $60 \mathrm{~km}$ of the study area is $6 \mathrm{~m} \mathrm{~km}^{-1}$ (370 m elevation change). The Smiths Fork-age ELAs also descend in elevation $\left(\sim 3 \mathrm{~m} \mathrm{~km}^{-1}\right)$ at the eastern end of the range, where most of the glaciers had equilibrium lines $10-40 \mathrm{~m}$ above the mean ( $\sim 100 \mathrm{~m}$ lower than those in the center of the range).

\section{Lapse rates and modern summer temperatures at the ELAs}

Based on the data from three SNOTEL sites, the RAWS and the records from Manilla, Utah and Evanston, linear regressions relating station elevation to $T_{\mathrm{s}}$ and $T_{\mathrm{a}}$ were determined:

$T_{\mathrm{S}}=-0.0067 z+30.324\left(n=7, r^{2}=0.95, P<0.001\right)$

$T_{\mathrm{a}}=-0.0053 z+16.319\left(n=7, r^{2}=0.94, P=0.001\right),(2)$

where $T$ is in ${ }^{\circ} \mathrm{C}$, and $z$ is the station elevation in meters. The summer adiabatic lapse rate for the northern Uintas is therefore $6.7^{\circ} \mathrm{C} \mathrm{km}^{-1}$, while the mean annual rate is $5.3^{\circ} \mathrm{C} \mathrm{km}^{-1}$. Based on Equation (1), $T_{\mathrm{s}}$ at the 19 Smiths Fork-age ELAs ranges from $8.7^{\circ}$ to $11.2^{\circ} \mathrm{C}$. From Equation (2) the modern $0^{\circ} \mathrm{C}$ summer isotherm is projected to lie above an elevation of $4500 \mathrm{~m}$ a.s.l., while modern mean annual temperatures at all the ELAs range from $-0.8^{\circ}$ to $1.2^{\circ} \mathrm{C}$.

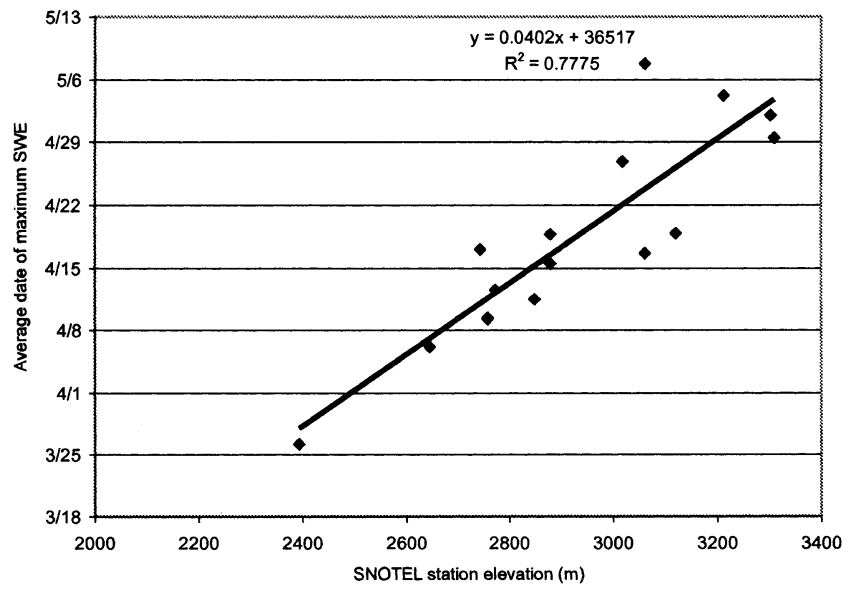

Fig. 4. Average date of the maximum annual snowpack as a function of SNOTEL site elevation.

\section{Modern winter snow accumulation at the ELAs}

Predicted water equivalents (in $\mathrm{mm}$ ) are related to SNOTEL site elevation $(z)$ as follows:

$$
\begin{aligned}
1 \text { April } & =0.3413 z-655 \\
& \left(n=16, r^{2}=0.55, P=0.016\right)
\end{aligned}
$$

Annual Maximum $=0.4326 z-859$

$$
\left(n=16, r^{2}=0.60, P=0.008\right) .
$$

The average date of the maximum water equivalent at the 16 SNOTEL sites ranges from to 26 March to 7 May. Figure 4 illustrates that the higher-elevation stations record their maximum after 1 April (gradient of 40 days km ${ }^{-1}, r^{2}=0.78$, $\mathrm{P}<0.001$ ). Accordingly, the annual maximum value was used as a proxy for winter snow accumulation instead of the 1 April measurement, to avoid the bias inherent in using the 1 April value for stations of different elevations (e.g. Locke, 1989).

Figure 5 shows the surface interpolated from the annual maximum values. The predicted values for the ELAs determined from Equation (4) range from 380 to $540 \mathrm{~mm}$. But Figure 6 illustrates that individual SNOTEL sites receive from $-32 \%$ to $+52 \%$ of the predicted values and that residuals at each of the ELAs range from $-25 \%$ to $+21 \%$. Correction of the predicted values at the ELAs using these residuals yields estimates of $P$ from 357 to $586 \mathrm{~mm}$.

\section{DISGUSSION}

\section{Modern snowfall distribution}

Based on the SNOTEL data, the modern snowfall distribution varies considerably across the Uintas, with some areas receiving $30 \%$ more or less snow than would be expected based on their elevation (Fig. 6). These substantial local variations in snow accumulation are likely related to prevailing winds and moisture-transport patterns.

The spatial variability of precipitation in the Uintas is further demonstrated by the coefficient of determination $\left(r^{2}\right)$ for the regression relating elevation and mean 1 April snowpack (Equation (3)), 0.55, which is below the range found for 13 mountain ranges in Colorado by Leonard (1989) $\left(r^{2}=0.58-0.99\right)$, and at the lower end of the range for 24 mountain ranges in the Great Basin by Zielinski and McCoy (1987) $\left(r^{2}=0.52-0.98\right)$. The regression between elevation and annual maximum snowpack (Equation (4)) is 


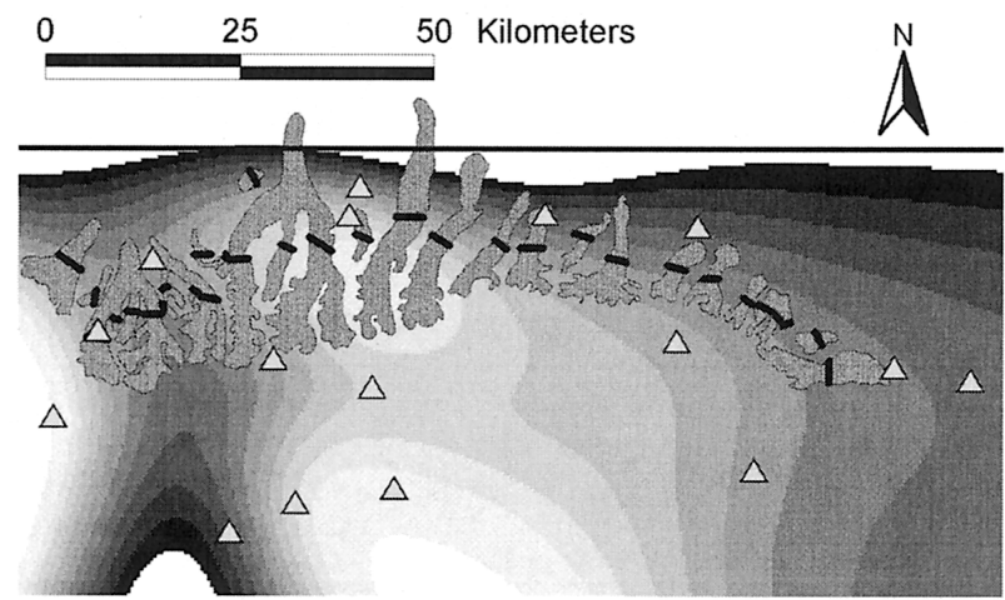

Nateline

$\triangle$ SNOTEL Sites

Weighted ELAs

Smiths Fork-age Glaciers

Mean Annual Max SWE (mm)

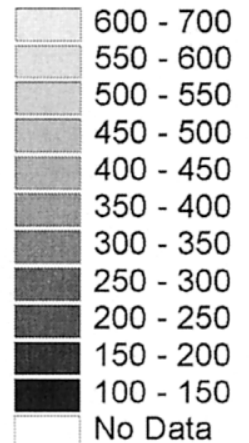

Fig. 5. Distribution of mean annual maximum SWE (in mm) across the Uintas for 1986-99. Lighter shading represents greater mean annual maximum SWE. The surface was interpolated from the 16 SNOTEL sites (triangles). The Smiths Fork-age glaciers are outlined, and their weighted ELAs are highlighted. The greatest modern winter accumulation is in the centers of the north and south slopes and at the far western end of the range.

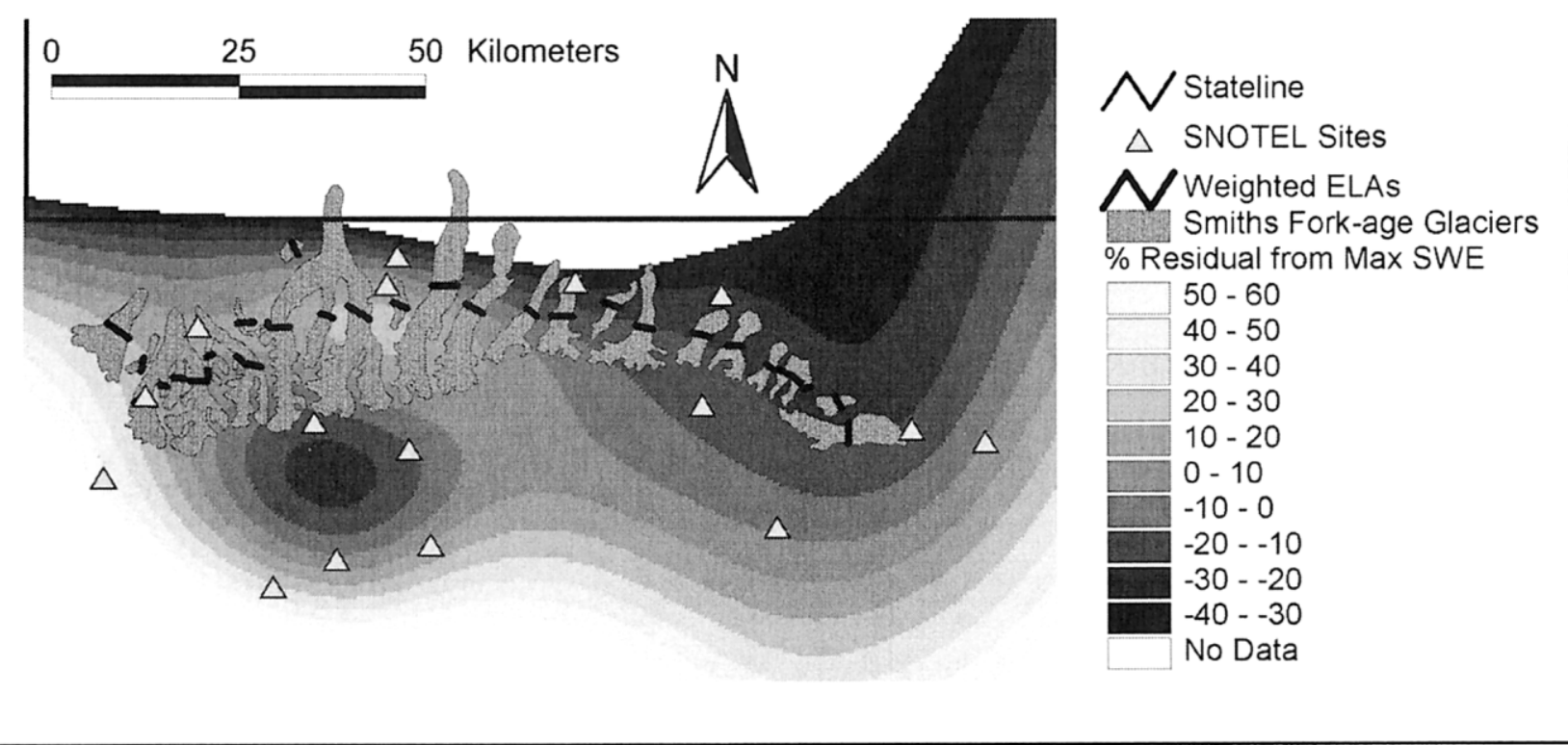

Fig. 6. Surface representing percentage residuals from the altitude-predicted (Equation (4)) mean annual maximum SWE across the Uintas for 1986-99. Symbols are the same as in Figure 5. The greatest negative deviation is in the northeast and just west of center on the south slope. The greatest positive deviation is at the extreme western end of the range.

slightly stronger $\left(r^{2}=0.60\right)$, suggesting that late-spring storms affect the entire range, balancing differences produced earlier in the winter by local storms.

The Uintas are also generally snow-starved today compared with other mountain ranges of the western United States. Mean 1 April water equivalent values in the Uintas are considerably lower than in most of the Great Basin ranges studied by Zielinksi and McCoy (1987). In addition, the gradient (from Equation (4)) of annual water equivalent values in the Uintas, $0.43 \mathrm{~m} \mathrm{~km}^{-1}$, is slightly lower than the $0.5 \mathrm{~m} \mathrm{~km}^{-1}$ considered typical of isolated topographic barriers, and significantly lower than the $1.2 \mathrm{~m} \mathrm{~km}^{-1}$ characteristic of the northern Rocky Mountain ranges (Porter and others, 1983). The lower gradient in the Uintas may be partially due to the numerous upwind mountain ranges in the Great Basin, which may diminish the amount of moisture reaching the Uintas. The modern SWE gradient $\left(1.37 \mathrm{~m} \mathrm{~km}^{-1}\right)$ on the western slope of the Wasatch Range, immediately west of the Uintas, is the steepest in the area studied by Zielinski and McCoy (1987), indicating the efficacy of this range at intercepting westerly-derived moisture.

Additional support for this interpretation comes from the surface interpolated from the snowpack residuals (Fig. 6), which reveals that the eastern half of the northern Uintas receives less snowfall than the western end of the range. Mitchell (1976) delineated a major climatic boundary, termed 


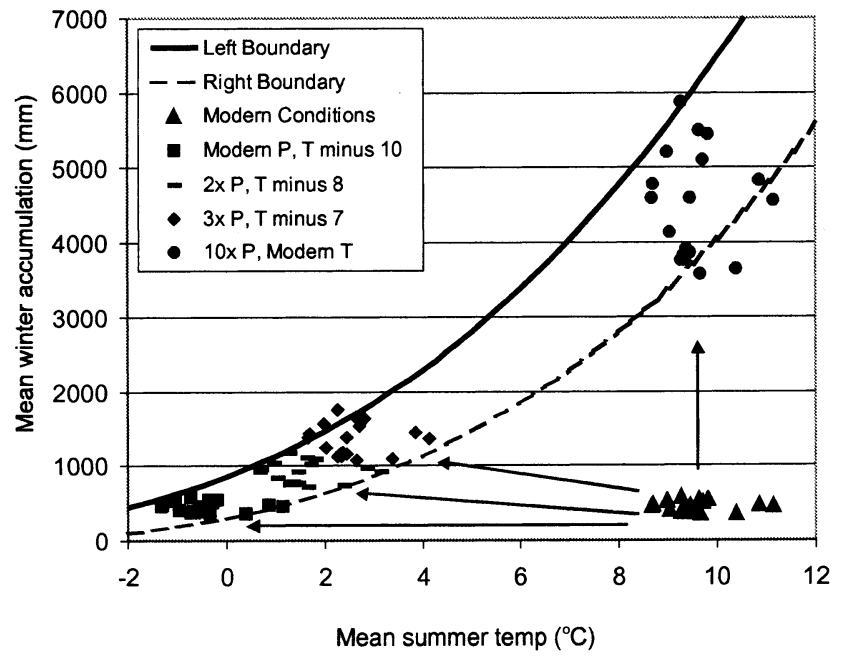

Fig. 7. Climate-space diagram for Smiths Fork-age ELAs. Modern $T_{\mathrm{s}}$ and $P$ at the ELAs plot in the lower right. If modern $T_{\mathrm{s}}$ were unchanged, $P$ would need to be increased $1000 \%$ to move the modern climate conditions into the range seen at modern ELAs. At the other extreme, a decrease in $T_{\mathrm{s}}$ of $10^{\circ} \mathrm{C}$ would be required if modern $P$ values remained constant. Increases of $200 \%$ or $300 \%$ in $P$ would require depressions of $T_{\mathrm{S}} 8^{\circ}$ and $7^{\circ} \mathrm{C}$, respectively.

the "winter boundary", which is present from November through March across northern Utah and the north slope of the Uintas. Because atmospheric circulation along the winter boundary is dominantly west to east, orographic precipitation probably depletes the moisture content of air masses as they pass along the Uintas, causing less snowfall on the eastern summits relative to the western ones (Houghton, 1979).

\section{ELAs and implications for Smiths Fork-age paleo- climate}

Several studies have presented data on the range of mean summer temperature $\left(T_{\mathrm{S}}\right)$ and winter precipitation $(P)$ values at modern glacier ELAs (Loewe, 1971; Leonard, 1989; Ohmura and others, 1992). Figure 7 shows an envelope that encloses most of the modern data points. The boundaries of this envelope are defined by the following equations from Kotlyakov and Krenke (1982) and Leonard (1989):

$$
\begin{aligned}
\text { Left Margin } & P=1.33\left(T_{\mathrm{s}}+9.66\right)^{2.85} \\
\text { Right Margin } & P=1.33\left(T_{\mathrm{s}}+6.66\right)^{2.85} .
\end{aligned}
$$

The values for modern $T_{\mathrm{s}}$ and $P$ at the Smiths Fork-age ELAs in the northern Uintas (listed in Table 3) plot in the lower right of this diagram. If modern $T_{\mathrm{s}}$ were unchanged, $P$ at the ELAs would need to be increased $1000 \%$ to move current climate conditions into the envelope of modern ELA conditions. At the other extreme, a decrease in $T_{\mathrm{s}}$ of $10^{\circ} \mathrm{C}$ would be required if modern $P$ values remained constant. Increases of $200 \%$ or $300 \%$ in $P$ would require depressions of $T_{\mathrm{S}}$ of $8^{\circ}$ and $7^{\circ} \mathrm{C}$, respectively. This analysis assumes that the distribution of snowfall during the LGM was similar to the modern distribution and that the change in $P$ was uniform at all 19 ELAs.

Seltzer (1994) completed a more sophisticated analysis linking the change in ELA ( $\triangle \mathrm{ELA})$ with changes in winter accumulation, heat input from radiation, and temperature. If it is assumed that the majority of ablation occurs during the summer, that the heat input from radiation is independent of elevation (Seltzer, 1994) and that the overall radi- ation input at the LGM was similar to the modern value (Berger, 1978), then Seltzer's equation 19 simplifies to:

$$
\Delta \mathrm{ELA}=\frac{\left(0.003^{\circ} \mathrm{Cmm}^{-1}\right)(\Delta P)-\Delta T_{\mathrm{s}}}{-0.0105^{\circ} \mathrm{C} \mathrm{m}^{-1}},
$$

where $\Delta \mathrm{ELA}$ is in meters, $\Delta P$ is in $\mathrm{mm}$ and $\Delta T_{\mathrm{s}}$ is in ${ }^{\circ} \mathrm{C}$.

Based on Equation (1), the modern $T_{\mathrm{s}}$ range between the 19 Smiths Fork-age ELAs is $2.5^{\circ} \mathrm{C}$ (Table 4). If the lapse rate for mean summer temperature was the same at the LGM, the western ELAs must have received $\sim 2000 \mathrm{~mm}$ more precipitation each winter than those in the center of the range to compensate for the warmer $T_{\mathrm{s}}$ value at lower elevations. Referencing the $P$ increase for each of the ELAs relative to the highest ELA (Middle Fork Beaver Creek, MFBC ELA $_{\text {) }}$ reveals that the lower ELAs received 5-2100 mm more $P$

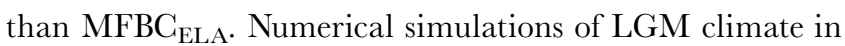
the vicinity of the western Uintas have indicated that precipitation was likely increased by a factor of 2 during the winter (Timofeyeva and others, 1999). Figure 7 shows that if $P$ were doubled at $\mathrm{MFBC}_{\mathrm{ELA}}, T_{\mathrm{S}}$ there would need to be depressed from $8^{\circ} \mathrm{C}$ to $5.5^{\circ} \mathrm{C}$ to reach the range of conditions at modern ELAs. Assuming a LGM $P$ that was double the modern value at $\mathrm{MFBC}_{\mathrm{ELA}}$, the estimated $P$ values for the 18 lower ELAs range from 943 to $3038 \mathrm{~mm}$ (Table 5). These values are greater than those interpreted by assuming a uniform change in $P$ for all 19 data points (Fig. 7) because they consider the independent effects of $T_{\mathrm{s}}$ and $P$ on the elevation of the former equilibrium lines. If these data are plotted in climate-space, with a uniform temperature decrease of $8^{\circ} \mathrm{C}$, all but one of the data points fall outside the envelope enclosing conditions at modern glacier ELAs (Fig. 8). Reducing the temperature decrease to $5.5^{\circ} \mathrm{C}$ allows all 19 data points to fit, suggesting that the actual LGM temperature depression was somewhere

\begin{tabular}{|c|c|c|c|c|c|}
\hline Glacier & $\begin{array}{c}E L A \\
\mathrm{~m}\end{array}$ & $\begin{array}{c}\mathrm{T} \\
{ }^{\circ} \mathrm{C}\end{array}$ & $\begin{array}{c}P \\
\mathrm{~mm}\end{array}$ & $\begin{array}{c}\text { Residual } \\
\% \\
\%\end{array}$ & $\begin{array}{c}\text { Weighted } P \\
\mathrm{~mm}\end{array}$ \\
\hline South Fork Ashley & 3115 & 9.5 & 490 & -21 & 387 \\
\hline North Fork Ashley & 3142 & 9.3 & 502 & -25 & 376 \\
\hline East Fork Carter Creek & 3084 & 9.7 & 476 & -25 & 357 \\
\hline West Fork Carter Creek & 3130 & 9.4 & 496 & -24 & 377 \\
\hline South Fork Sheep Creek & 3135 & 9.3 & 498 & -23 & 384 \\
\hline Middle Fork Sheep Creek & 3129 & 9.4 & 496 & -21 & 392 \\
\hline Burnt Fork & 3176 & 9.0 & 516 & -20 & 413 \\
\hline Thompson Creek & 3136 & 9.3 & 499 & -24 & 379 \\
\hline Middle Fork Beaver Creek & 3231 & 8.7 & 540 & -15 & 459 \\
\hline West Fork Beaver Creek & 3227 & 8.7 & 538 & -11 & 479 \\
\hline Henrys Fork & 3187 & 9.0 & 521 & 0 & 521 \\
\hline Smiths Fork & 3114 & 9.5 & 490 & -6 & 460 \\
\hline West Fork Smiths & 3142 & 9.3 & 502 & 17 & 587 \\
\hline Blacks Fork & 3089 & 9.6 & 478 & 15 & 550 \\
\hline Little West Fork Blacks & 2976 & 10.4 & 430 & -15 & 365 \\
\hline East Fork Bear & 3075 & 9.7 & 473 & 8 & 511 \\
\hline Hayden Fork Bear River & 3059 & 9.8 & 466 & 17 & 545 \\
\hline Gold Hill & 2905 & 10.9 & 399 & 21 & 483 \\
\hline West Fork Bear & 2861 & 11.2 & 380 & 20 & 456 \\
\hline Average & 3101 & 9.5 & 484 & - & 446 \\
\hline
\end{tabular}
between $8^{\circ}$ and $5.5^{\circ} \mathrm{C}$.

Table 4. Modern $T_{\mathrm{s}}$ and $P$ at Smiths Fork-age ELAs

Notes: $T_{\mathrm{S}}$ is calculated with Equation (1). $P$ is calculated from Equation (4). The $\%$ residual was determined from the location of the ELA in the distribution of modern residuals shown in Figure 6 . The weighted $P$ value was determined by adjusting predicted values by the residual percentage. 


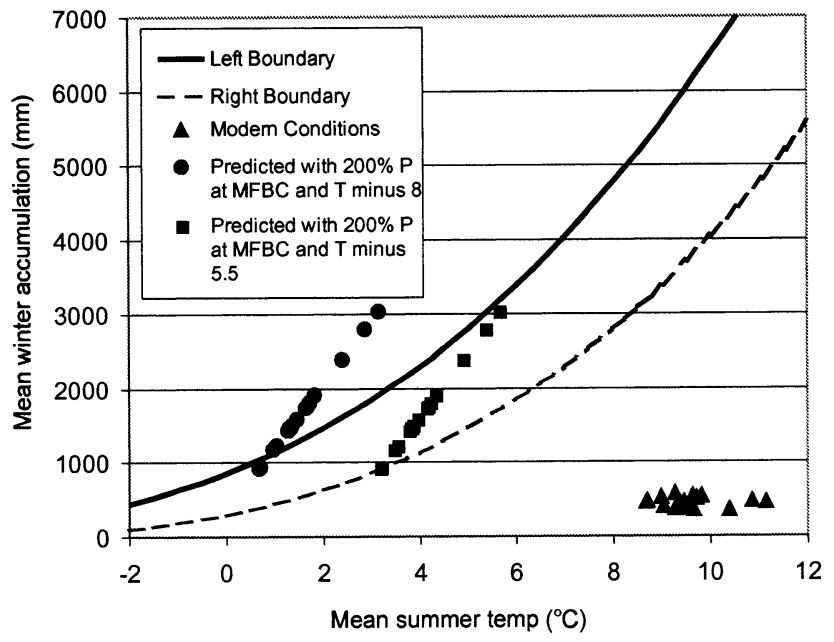

Fig. 8. Climate-space diagram showing possible $T_{\mathrm{s}}$ and $P$ changes for the Smiths Fork Glaciation. Values for P were computed from Equation (7) assuming 200\% P at the highest ELA and the modern summer lapse rate. Only one of the data points falls within the envelope when plotted with a uniform $8^{\circ} \mathrm{C}$ temperature depression. However, a $T_{\mathrm{s}}$ depression of $5.5^{\circ} \mathrm{C}$ allows all the points to fall within the envelope, suggesting that the actual LGM temperature depression (taking into account non-uniform changes in $P$ ) may have been closer to $5.5^{\circ} \mathrm{C}$.

\section{Importance of pluvial Lake Bonneville}

The reconstructed mean ELA of $3100 \mathrm{~m}$ a.s.l. during the Smiths Fork Glaciation compares favorably with the value of $3000 \mathrm{~m}$ proposed previously for the Uintas by Porter and others (1983, fig. 4-2) and with the range 2620-3310 m proposed by Schlenker (1995, table 15). Moreover, Flint (1971, fig. 18-4) indicates that the lowest elevation of cirque floors in the Uintas is about $3050 \mathrm{~m}$ a.s.l. However, the non-uniform east-west variation in ELA (Fig. 3) was not previously recognized.

Summits at the western end of the Uintas are the first to intercept moisture advected by prevailing westerly winds along the winter boundary defined by Mitchell (1976). Yet the modern $P$ increase at the western end of the range compared with the range center is considerably less than the $800-2000 \mathrm{~mm}$ required to explain the $370 \mathrm{~m}$ decrease in ELA between these two locations (from Equation (7)). Moreover, adjusted values of $P$ do decrease somewhat across the study area, but the values at the highest ELAs $(459,479,521 \mathrm{~mm})$ are similar to the values at the lowest ELAs (483 and $456 \mathrm{~mm}$ ).

Therefore, a change in prevailing wind direction or proximity to a moisture source is required to explain the more dramatic increase in winter precipitation in the western Uintas during the Smiths Fork Glaciation. Because orographic shielding by upwind mountains reduces downwind precipitation (Houghton, 1979), ELAs should rise in a downwind direction if the local lapse rate remains constant. The eastward rise in ELA along the western half of the north slope documented in Figure 3 suggests that prevailing winds did carry moisture from west to east during the LGM, as they do today. Support for this interpretation comes from Moran (1974) and Zielinski and McCoy (1987) who concluded that circulation patterns across the northern Great Basin in the vicinity of the winter boundary during the late Pleistocene were similar to those today. In addition, climate simulations using a global circulation model suggest that the North American jet stream and storm tracks were displaced southward by the Laurentide ice sheet (COHMAP members, 1988), reinforcing a dominantly westerly airflow through this region.

If prevailing winds were carrying moisture to the Uintas from the west during the LGM, then the presence of pluvial Lake Bonneville $\sim 100 \mathrm{~km}$ upwind of the western Uintas

Table 5. Change in P required by the difference in Smiths Fork-age paleo-ELAs

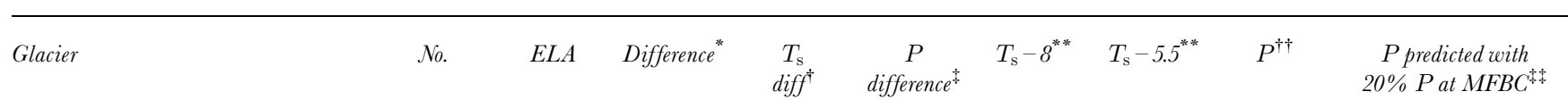

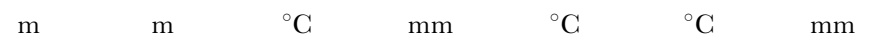

South Fork Ashley

North Fork Ashley

East Fork Carter Creek

West Fork Carter Creek

South Fork Sheep Creek

Middle Fork Sheep Creek

Burnt Fork

Thompson Creek

Middle Fork Beaver Creek (MFBC)

West Fork Beaver Creek

Henrys Fork

Smiths Fork

West Fork Smiths

Blacks Fork

Little West Fork Blacks

East Fork Bear

Hayden Fork Bear River

Gold Hill

West Fork Bear

Average

$0.8 \quad 663 \quad 1.5$

$\begin{array}{rr}3115 & -116 \\ 3142 & -89 \\ 3084 & -147 \\ 3130 & -101 \\ 3135 & -96 \\ 3129 & -102 \\ 3176 & -55 \\ 3136 & -95 \\ 3231 & 0 \\ 3227 & -4 \\ 3187 & -44 \\ 3114 & -117 \\ 3142 & -89 \\ 3089 & -143 \\ 2976 & -255 \\ 3075 & -156 \\ 3059 & -172 \\ 2905 & -326 \\ 2861 & -370\end{array}$

$\begin{array}{rr}0.8 & 663 \\ 0.6 & 508 \\ 1.0 & 844 \\ 0.7 & 581 \\ 0.6 & 552 \\ 0.7 & 587 \\ 0.4 & 316 \\ 0.6 & 543 \\ 0.0 & 0 \\ 0.0 & 25 \\ 0.3 & 252 \\ 0.8 & 670 \\ 0.6 & 510 \\ 1.0 & 817 \\ 1.7 & 1464 \\ 1.0 & 893 \\ 1.2 & 984 \\ 2.2 & 1867 \\ 2.5 & 2120\end{array}$

1.5
1.3
1.7
1.4
1.3
1.4
1.0
1.3
0.7
0.7
1.0
1.5
1.3
1.6
2.4
1.7
1.8
2.9
3.2
1.5

1.5

4.0
3.8
4.2
3.9
3.8
3.9
3.5
3.8
3.2
3.2
3.5
4.0
3.8
4.1
4.9
4.2
4.3
5.4
5.7

$\begin{array}{rr}387 & 1581 \\ 376 & 142 \\ 357 & 176 \\ 377 & 149 \\ 384 & 147 \\ 392 & 150 \\ 413 & 123 \\ 379 & 1461 \\ 459 & 918 \\ 479 & 943 \\ 521 & 117 \\ 460 & 158 \\ 587 & 142 \\ 550 & 173 \\ 365 & 238 \\ 511 & 1811 \\ 545 & 190 \\ 483 & 278 \\ 456 & 303 \\ & \\ 446 & 166\end{array}$

\footnotetext{
Elevation difference between ELA and MFBC ELA (No. 9). ${ }^{\dagger}$ Difference in mean summer temperature between ELA and MFBC ELA, from Equation (1).

${ }^{*}$ Increase in winter precipitation at ELA relative to MFBC ELA from Equation (7). ${ }^{* *}$ Modern mean summer temperature at ELA minus $8^{\circ}$ or $5.5^{\circ} \mathrm{C}$.

${ }^{\dagger}$ Modern weighted winter snow accumulation at ELA. ${ }^{+*}$ Predicted winter snow accumulation with doubled precipitation MFBC ELA.
} 


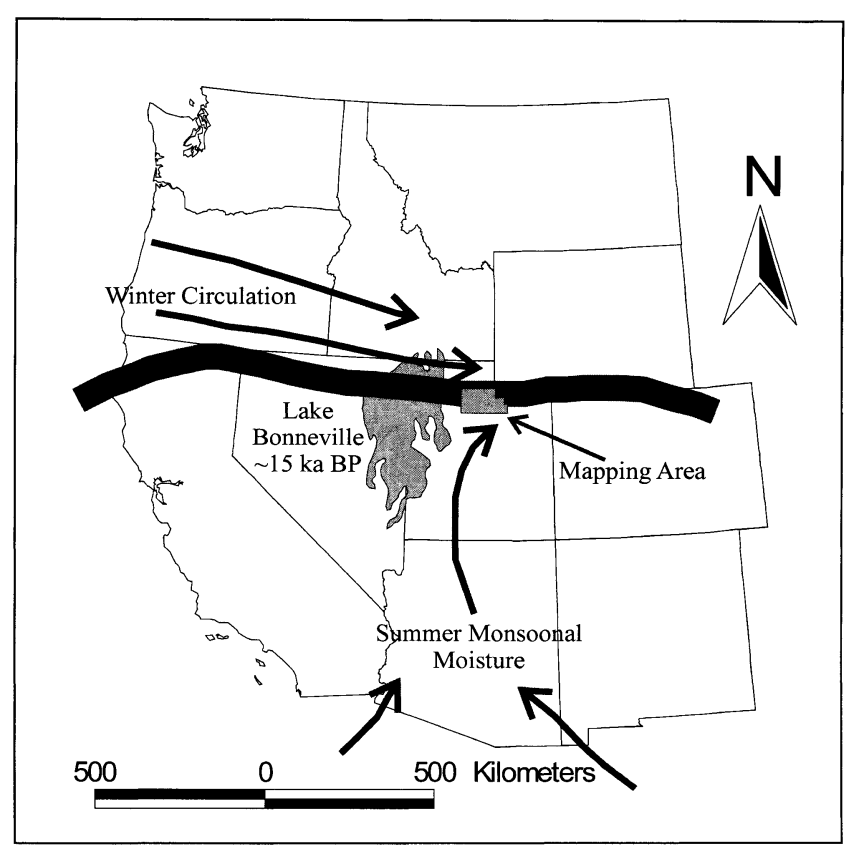

Fig. 9. Modern atmospheric circulation in the western United States. Solid black line is the winter boundary (Mitchell, 1976).

would have greatly increased moisture availability (Fig. 9). Lake Bonneville reached its maximum surface elevation of $1550 \mathrm{~m}$ a.s.l. around $15 \mathrm{kyr}$ BP, covering an area of $51700 \mathrm{~km}^{2}$ (O'Connor, 1993). Although the lake reached its maximum extent a few thousand years after the LGM, it was present during the Smiths Fork maximum and was certainly larger than the modern Great Salt Lake (Oviatt, and others, 1992; Oviatt, 1997). Numerical simulations of the LGM paleoclimate in the Bonneville basin suggest that the mean monthly maximum temperatures in the basin were below $0^{\circ} \mathrm{C}$ only in January and December (Craig and others, 1997; Timofeyeva and others, 1999). This result indicates that open water was likely present in the early and late winter. This moisture source, combined with the abrupt topography of the Wasatch Front and western Uintas, probably produced tremendous lake-effect snow. This extreme loading of winter precipitation would have forced lower ELAs at the western end of the Uintas despite the warmer $T_{\mathrm{S}}$ values at the lower elevations.

\section{LGM ELA depression}

Figure 8 demonstrates that a twofold increase in $P$ at $\mathrm{MFBC}_{\text {ELA }}$ during the LGM would have been accompanied by a $5.5^{\circ} \mathrm{C}$ temperature depression and non-uniform precipitation changes at ELAs across the northern Uintas (Craig and others, 1997; Timofeyeva and others, 1999). The magnitude of LGM ELA depression ( $\triangle \mathrm{ELA})$ can be determined from these data by substituting values of $P$ (estimated from the elevation difference between each equilibrium line and $\mathrm{MFBC}_{\mathrm{ELA}}$ ) and a $T_{\mathrm{S}}$ decrease of $5.5^{\circ} \mathrm{C}$ into Equation (7). Estimates of $\triangle \mathrm{ELA}$ for the LGM obtained this way range from 650 to $1250 \mathrm{~m}$, with a mean of $900 \mathrm{~m}$, suggesting that previous estimates ( 1475 m from Schlenker, 1995; 1000 m from Richmond, 1965), which were based solely on inferred summer temperature changes, are too great.

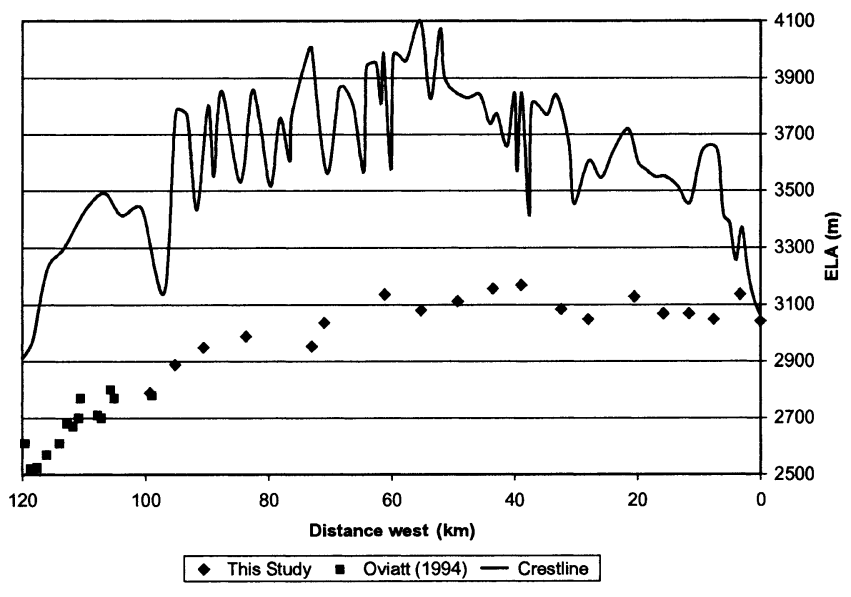

Fig. 10. Reconstructed ELAs across the entire north slope of the Uintas from a THAR of 0.40. Points west of $100 \mathrm{~km}$ are from Oviatt (1994).

\section{GONGLUSIONS}

Nineteen valleys of the northern Uinta Mountains contained alpine glaciers during the LGM Smiths Fork Glaciation. Reconstructed ELAs for these glaciers range in elevation from 2860 to $3230 \mathrm{~m}$ a.s.l., with a mean of $3100 \mathrm{~m}$. Modern $T_{\mathrm{s}}$ and $P$ at these ELAs range from $8.7^{\circ}$ to $11.2^{\circ} \mathrm{C}$, and from 357 to $586 \mathrm{~mm}$. Translation of these conditions into the range of $T_{\mathrm{s}}$ and $P$ values seen at modern glacier ELAs requires $T_{\mathrm{s}}$ depressions of $10^{\circ} \mathrm{C}$ with no change in $P, 8^{\circ} \mathrm{C}$ with $200 \% P, 7^{\circ} \mathrm{C}$ with $300 \% P$, and $1000 \% P$ with no change in $T_{\mathrm{s}}$. Independent consideration of changes in $T_{\mathrm{s}}$ and $P$ reveals that if the modern summer lapse rate was unchanged at the LGM, and $P$ at the highest ELA was 200\% of the modern value, then $P$ at the lower ELAs ranged from 943 to $3038 \mathrm{~mm}$, and $T_{\mathrm{s}}$ depression was $8-5.5^{\circ} \mathrm{C}$.

The $370 \mathrm{~m}$ vertical difference between the highest and lowest Smiths Fork-age ELAs requires up to $2000 \mathrm{~mm}$ of additional $P$ at the western end of the range. This is much greater than the modern difference in $P$, suggesting that moisture derived from pluvial Lake Bonneville lowered the ELAs in the western Uintas. Support for this theory comes from the work of other researchers in the extreme western Uintas and Wasatch Mountains. Oviatt (1994) reconstructed 14 LGM valley glaciers in the headwaters of the Weber River, west of the study area for this project, and estimated their ELAs with the THAR method. When these data are plotted with the THAR estimates from Table 2, ELAs for the extreme westernmost glaciers are shown to be $\sim 700 \mathrm{~m}$ lower $(\sim 2500 \mathrm{~m}$ a.s.l.) than those in the center of the range (Fig. 10). Furthermore, ELA estimates for glaciers in Bells Canyon and Little Cottonwood Canyon, $\sim 40 \mathrm{~km}$ further west in the Wasatch Range, are $\sim 2400$ $m$ a.s.l., continuing the downward ELA trend to the shoreline of Lake Bonneville (Madsen and Currey, 1979). These estimates were made using a THAR of 0.50 ; a THAR of 0.40 would yield an even lower elevation, providing additional evidence of enhanced precipitation downwind of Lake Bonneville.

The overall $\triangle$ ELA during the LGM in the northern Uintas, taking into account uniform changes in summer temperature, a doubling of winter accumulation at the highest ELA, and increased snowfall at the western end of the range, was approximately $900 \mathrm{~m}$. This is $100-500 \mathrm{~m}$ less than previous estimates (e.g. Richmond, 1965; Schlenker, 1995), demonstrating the effect of considering both temperature and precipitation when interpreting past changes in ELAs. 


\section{ACKNOWLEDGEMENTS}

E. Carson, D. Douglass, J. M. Duque and L. M. de Frutos provided assistance in the field. The U.S. Forest Service assisted with field logistics. K. A. Brugger, D. Clark and Scientific Editor N. R. Iverson provided thoughtful reviews that greatly improved the clarity of the original manuscript.

\section{REFERENCES}

Atwood, W.W. 1909. Glaciation of the Uinta and Wasatch Mountains. U.S Geol. Surv. Prof. Pap. 61.

Berger, A. L. 1978. Long-term variations of caloric insolation resulting from the Earth's orbital elements. Quat. Res., 9(2), 139-167.

Brugger, K. A. 1996. Implications of till-provenance studies for glaciological reconstructions of the paleoglaciers of Wildhorse Canyon, Idaho, U.S.A. Ann. Glaciol., 22, 93-101.

Brugger, K. A. and B. S. Goldstein. 1999. Paleoglacier reconstruction and late Pleistocene equilibrium-line altitudes, southern Sawatch Range, Colorado. In Mickelson, D. M. and J.W. Attig, eds. Glacial processes: past and present. Boulder, CO, Geological Society of America, 103-112. (Special Paper 337.)

Bryant, B. 1992. Geologic and structure maps of the Salt Lake City $1^{\circ} \times 2^{\circ}$ quadrangle, Utah and Wyoming. Washington, D.C., U.S. Geological Survey. (Misc. Invest. Ser. I-1997, scale 1:125,000.)

Bursik, M. I. and A. R. Gillespie. 1993. Late Pleistocene glaciation of Mono basin, California. Quat. Res., 39 (1), 24-35.

COHMAP members. 1988. Climatic changes of the last 18,000 years: observations and model simulations. Science, 241 (4869), 1043-1052.

Craig, R. G., M. M. Timofeyeva and S. M. Clement. 1997. Simulation of climate and runoff for the Bonneville Basin at the Last Glacial Maximum. Geol. Soc. Am. Abstr. Programs, 29(6), 254.

Flint, R. F. 1971. Glacial and Quaternary geology. New York, etc., John Wiley and Sons Inc.

Fullerton, D. S. 1986. Stratigraphy and correlation of glacial deposits from Indiana to New York and New Jersey. Quat. Sci. Rev., 5(1-4), 23-37.

Gillespie, A. R. 1991. Testing a new climatic interpretation for the Tahoe glaciation. In Hall, C. A., V. Doyle-Jones and B. Widawski, eds. Natural history of eastern California and high-altitude research. Los Angeles, University of California. White Mountain Research Station, 383-398. (Symposium 3.)

Hawkins, F. F. 1985. Equilibrium-line altitudes and paleoenvironment in the Merchants Bay area, Baffin Island, N.W.T., Canada. F. Glaciol., 31 (109), 205-213.

Houghton, J. G. 1979. A model for orographic precipitation in the northcentral Great Basin. Mon. Weather Rev., 107, 1462-1475.

Kotlyakov, V. M. and A. N. Krenke. 1982. Investigations of the hydrological conditions of alpine regions by glaciological methods. International Association of Hydrological Sciences Publication 138 (Symposium at Exeter 1982 Hydrological Aspects of Alpine and High Mountain Areas), 31-42.

Leonard, E. M. 1984. Late Pleistocene equilibrium-line altitudes and modern snow accumulation patterns, SanJuan Mountains, Colorado, U.S.A. Arct. Alp. Res., 16(1), 65-76.

Leonard, E. M. 1989. Climatic change in the Colorado Rocky Mountains: estimates based on modern climate at Late Pleistocene equilibriumlines. Arct. Alp. Res., 21 (3), 245-255.

Locke, W.W., III. 1989. Comment on "Paleoclimatic implications of the relationship between modern snowpack and late Pleistocene equilibriumline altitudes in the mountains of the Great Basin, western U.S.A." Arct. Alp. Res., 21 (1), 97-101.

Locke, W.W. 1990. Late Pleistocene glaciers and climate of western Montana, U.S.A. Arct. Alp. Res., 22 (1), 1-13.

Loewe, F. 1971. Considerations on the origin of the Quaternary ice sheet of North America. Arct. Alp. Res., 3(4), 331-344.
Madsen, D. B. and D. R. Currey. 1979. Late Quaternary glacial and vegetation changes, Little Cottonwood Canyon area, Wasatch Mountains, Utah. Quat. Res., 12, 254-270.

Meier, M. F. and A. S. Post. 1962. Recent variations in mass net budgets of glaciers in western North America. International Association of Scientific Hydrology Publication 58 (Symposium at Obergurgl 1962 - Variations of the Regime of Existing Glaciers), 63-77.

Meierding, T. C. 1982. Late Pleistocene glacial equilibrium-line altitudes in the Colorado Front Range: a comparison of methods. Quat. Res., 18(3), 289-310.

Mitchell, V. L. 1976. The regionalization of climate in the western United States. 7. Appl. Meteorol., 15, 920-927.

Moran, J. M. 1974. Possible coincidence of a modern and a glacial-age climatic boundary in the montane west, United States. Arct. Alp. Res., 6(3), 319-321.

O'Connor, J. E. 1993. Hydrology, hydraulics, and geomorphology of the Bonneville flood. Boulder, CO, Geological Society of America. (GSA Special Paper 274.)

Ohmura, A., P. Kasser and M. Funk. 1992. Climate at the equilibrium line of glaciers. F. Glaciol., $\mathbf{3 8}(130), 397-411$.

Osborn, G. 1989. Glacial deposits and tephra in the Toiyabe Range, Nevada, U.S.A. Arct. Alp. Res., 21 (3), 256-267.

Oviatt, C. G. 1994. Quaternary geologic map of the upper Weber River drainage basin, Summit County, Utah. Utah Geological Survey. (Map 156, scale 1:50,000.)

Oviatt, G. G. 1997. Lake Bonneville fluctuations and global climate change. Geology, 25(2), 155-158.

Oviatt, G. G., D. R. Gurrey and D. Sack. 1992. Radiocarbon chronology of Lake Bonneville, eastern Great Basin, U.S.A. Palaeogeogr., Palaeoclimatol., Palaeoecol., 99(3-4), 225-241.

Paterson, W. S. B. 1994. The physics of glaciers. Third edition. Oxford, etc., Elsevier.

Pierce, K. L. 1979. History and dynamics of glaciation in the northern Yellowstone National Park area. U.S. Geol. Surv. Prof. Pap. 729-F.

Pierce, K. L. 1982. Pleistocene glaciation threshold, modern snowpacks, and Pleistocene glacial activity, transect across western U.S. Geol. Soc. Am. Abstr. Programs, $14(7), 558$.

Porter, S. C. 1975. Equilibrium-line altitudes of Late Quaternary glaciers in the Southern Alps, New Zealand. Quat. Res., 5(1), 27-47.

Porter, S. C. 1979. Hawaiian glacial ages. Quat. Res., 12(2), 161-187.

Porter, S. C., K. L. Pierce and T. D. Hamilton. 1983. Late Wisconsin mountain glaciation in the western United States. In Wright, H. E., Jr, ed. Late-Quaternary environments of the United States. Volume 1. Minneapolis, MN, University of Minnesota Press, 71-111.

Richmond, G. M. 1965. Glaciation of the Rocky Mountains. In Wright, H. E., Jr and D. G. Frey, eds. The Quaternary of the United States. Princeton, NJ, Princeton University Press, 217-230.

Schlenker, G. C. 1995. Reconstruction of late-Pleistocene equilibrium-line altitudes and paleoenvironment: Uinta Mountains, Utah and Wyoming. (Ph.D. thesis, Texas A \& M University.)

Scott, W. E. 1977. Quaternary glaciation and volcanism, Metolius River, Oregon. Geol. Soc. Am. Bull., 88(1), 113-124.

Seltzer, G. O. 1994. Climatic interpretation of alpine snowline variations on millennial time scales. Quat. Res., 41 (2), 154-159.

Timofeyeva, M., S. Clement and R. Craig. 1999. Estimates of glacial climate and runoff for the Bonneville Basin. In Wilson, R. and L. Buffaloe, eds. Proceedings of the Fifteenth Annual Pacific Climate (PACLIM) Workshop, 27-30 April 1998. Sacramento, CA, California Department of Water Resources, 9-19. (Interagency Ecological Studies Program Technical Report 64.)

Torsnes, I., N. Rye and A. Nesje. 1993. Modern and Little Ice Age equilibrium-line altitudes on outlet valley glaciers from Jostedalsbreen, western Norway: an evaluation of different approaches to their calculation. Arct. Alp. Res., 25(2), 106-116.

Zielinski, G. A. and W. D. McCoy. 1987. Paleoclimatic implications of the relationship between modern snowpack and late Pleistocene equilibrium-line altitudes in the mountains of the Great Basin, western U.S.A. Arct. Alp. Res., 19(2), 127-134. 